atrics 72:221-223

15. Stossel TP 1973 Evaluation of opsonic and leukocyte function with a spectrophotometric test in patients with infection and with phagocytic disorders. Blood 42:121-130

16. Dossett JH, Williams RC Jr, Quie PG 1969 Studies on interaction of bacteria, serum factors, and polymorphonuclear leukocytes in mothers and newborns. Pediatrics 44:49-57

17. Lehrer RI. 1981. Ingestion and destruction of Candida albicans. In: Adams DO, Edelson PJ, Koren HS (eds) Methods for Studying Mononuclear Phagocytes. Academic Press Inc., New York, pp 693-708

18. Selsted ME, Szklarek D, Ganz T, Lehrer RI 1985 Activity of rabbit leukocyte peptides against Candida albicans. Infect Immun 49:202-206

19. Ganz T, Selsted ME, Szklarek D, Harwig SSL, Daher K, Bainton DF, Lehrer RI 1985 Defensins. Natural peptide antibiotics of human neutrophils. J Clin Invest 76:1427-1435

20. Zeligs BJ, Nerurkar LS, Bellanti JA 1984 Chemotactic and candidacidal responses of rabbit alveolar macrophages during postnatal development and the modulating roles of surfactant in these responses. Infect Immun 44:379385

21. Lehrer RI 1975 The fungicidal mechanisms of human monocytes. I. Evidence for myeloperoxidase-linked and myeloperoxidase-independent candidacidal mechanisms. J Clin Invest 55:338-346
22. Catterall JR, Black CM, Leventhal JP, Rizk NW, Wachtel JS, Remington JS 1987 Nonoxidative microbicidal activity in normal human alveolar and peritoneal macrophages. Infect Immun 55:1635-1640

23. Nerurkar LS, Zeligs BJ, Bellanti JA 1977 Maturation of the rabbit alveolar macrophage during animal development. II. Biochemical and enzymatic studies. Pediatr Res 11:1202-1207

24. Sherman MP, Lehrer RI 1985 Oxidative metabolism of neonatal and adult rabbit lung macrophages stimulated by opsonized group B streptococci. Infect Immun 47:26-30

25. Ganz T, Sherman MP, Selsted ME, Lehrer RI 1985 Newborn rabbit alveolar macrophages are deficient in two microbicidal cationic peptides, MCP-1 and MCP-2. Am Rev Respir Dis 132:901-904

26. Zimmerman JJ 1986 Pharmacologic modulation by prostaglandin $E_{1}$ of superoxide anion production by human polymorphonuclear leukocytes. Crit Care Med 14:761-767

27. O'Neill SJ, Sitar DS, Klass DJ, Taraska VA, Kepron W, Mitenko PA 1986 The pulmonary disposition of theophylline and its influence of human alveolar macrophage bactericidal function. Am Rev Respir Dis 134:12251228

28. Mammel MC, Fitterman C, Coleman M, Boros SJ 1987 Short-term dexamethasone therapy for bronchopulmonary dysplasia: acute effects and 1-year follow-up. Dev Pharmacol Ther 10:1-11

\title{
Richard D. Rowe Award
}

The Richard D. Rowe Award in Perinatal Cardiology has been established by the colleagues, trainees, and friends of Dr. Rowe to mark his many achievements in this field. Dr. Rowe was very proud of the award. While all of us are deeply saddened by his sudden illness and death, we hope the qualities everyone admired-his deep and unflinching commitment to excellence in practice, research, and training; his strength in crisis, his tremendous integrity, and, above all, his humility-will serve as models for the coming generation of physicians and scientists.

The award is a prize of $\$ 750$ to be presented annually at the meeting of the Society for Pediatric Research for the best work by a young investigator within three years of completing postdoctoral MD or PhD fellowship training. The award was judged this year on the basis of the abstract and presentation; but in the future, submission of a short paper, a curriculum vitae, and a letter from the sponsor also will be required.

Dr. Einat Birk is the 1988 winner of the Richard D. Rowe Award. She is a fellow of Dr. Abraham Rudolph at the Cardiovascular Research Institute, University of California, San Francisco. Her presentation was titled: Fetal thyroidectomy reduces postnatal myocardial beta adrenergic receptor responses in newborn lambs. Coauthors were Drs. Abraham Rudolph and James Roberts. 